\title{
ANALISA RESIKO PEMBANGUNAN JALAN TOL NUSA DUA-NGURAH RAI-TANJUNG BENOA TERHADAP TSUNAMI
}

\author{
(Risk Analysis Of Nusa Dua-Ngurah Rai-Tanjung Benoa Toll Road \\ Development Towards Tsunami)
}

\section{Edwin Hidayat ${ }^{1}$}

Diterima : 25 September $2012 \quad$ Disetujui: 11 januari 2013

\begin{abstract}
Abstrak : Lokasi pembangunan jalan tol Nusa Dua-Ngurah Rai- Benoa berada disekitar pantai yang rawan bencana tsunami sehingga di lakukan analisa dengan menggunakan pendekatan model Building Tsunami Vulnerability (BTV) dari Omira et al (2009), pendekatan Matriks bahaya Tsunami dari Sengaji dan Nababan (2009), dan pendekatan model Coastal Vulnerability Indeks (CVI) dari Kumar et al (2010). Nilai BTV jalan tol Nusa dua-Ngurah RaiBenoa adalah $30 \%$ yang termasuk dalam kelas resiko D1 yang artinya terdapat sedikit kerusakan namun tidak ada kerusakan pada struktur. Hasil perhitungan didapatkan nilai 4 yang berarti masuk pada kelas resiko 4, artinya mempunyai resiko tinggi. Terakhir dengan menggunakan pendekatan CVI didapatkan nilai 16,53 , artinya mempunyai resiko sedang. Hasilnya mempunyai nilai yang berbeda karena parameter dan nilai koefisien yang dihitung juga berbeda, yang perlu diperhatikan adalah parameter run up Tsunami dan jenis material bangunan yang menjadi factor paling dominan. Kesimpulannya, jalan tol Nusa Dua - Ngurah Rai - Benoa mempunyai tingkat kerentanan terhadap Tsunami, sehingga perlu dipersiapkan rencana mitigasi atau adaptasi jika terjadi force majeur, minimal pembuatan jalur evakuasi.
\end{abstract}

Kata Kunci: Tsunami, Kerentanan, Force Majeur, Jalan Tol, Bali

Abstract : The construction of Nusa Dua - Ngurah Rai - Benoa Toll Road in coastal area which has vulnerability of tsunami so for measure the level of vulnerability use the Building Tsunami Vulnerability (BTV) from Omira et al (2009), Tsunami Matrix from Sengaji and Nababan (2009), and Coastal Vulnerability Indeks (CVI) by Kumar et al (2010). The result of BTV is 30\%, this value included in the class risk D1 which has meaning slight no structural damage. Then with the result showed the value is 4 and include in the class risk 4 which the meaning is high risk. Lastly, measuring with CVI model the result is 16,53 this included in the class risk moderate. We had different results, it is because the parameter and the coefficient value were calculated also different. Furthermore, the parameters tsunami run-up and the type of building materials are parameters which need to be most consider, these parameters are the most dominant factor. It can be concluded that the Nusa Dua - Ngurah Rai - Benoa toll road has vulnerability to Tsunami. Thus, we must preparing the mitigation or adaptation plan, such as, evacuation routes plan, if forece majeur happened.

Key Words: Tsunami, Vulnerability, Force Majeur, Toll Road, Bali

\footnotetext{
${ }^{1}$ Puslitbang Jalan dan Jembatan, Kementerian Pekerjaan Umum

Jl. A.H. Nasution No. 264 Bandung 40294
} 


\section{Pendahuluan}

Seiring dengan bertambahnya jumlah penduduk di Indonesia, kebutuhan akan transportasi juga semakin meningkat, Data dari BPS (2012) pertumbuhan kendaraan di Indonesia dari tahun 2000-2010 setiap tahun meningkat antara 9\%-27\%. Salah satu propinsi yang pertumbuhan kendaraannya tinggi adalah Provinsi Bali. Berdasarkan Perda Provinsi Bali No.6/2009 tentang Rencana Pembangunan Jangka Panjang Daerah (RPJPD) Provinsi Bali Tahun 2005-2025, pertumbuhan kendaraan bermotor di Bali dari tahun 20012006 adalah $12,43 \%$. Dan yang menghawatirkan adalah tingkat pelayanan jalan, atau ruasruas jalan yang $\mathrm{V} / \mathrm{C}$ rasionya lebih dari dari 0,60 atau telah mengalami kemacetan lalu lintas diantaranya ruas jalan Antosari-Tabanan (0,72), Kediri-Mengwitani (0,72), Mengwitani-Denpasar (0,76), Simpang Cokroaminoto-Simpang Tohpati $(0,66)$, SakahBlahbatuh (0,74), Blahbatuh-Semebaung $(0,60)$, Semebaung-Gianyar $(0,85)$, Gianyar-Sidan $(0,72)$, Sidan-Klungkung $(0,67)$, Klungkung-Anggentelu $(0,66)$, DenpasarPesanggaran $(0,83)$ dan Denpasar-Tuban $(0,86)$.

Seperti kita ketahui Propinsi Bali merupakan daerah tujuan wisata di Indonesia, jika tidak ditangani secara serius kemacetan dapat mempengaruhi tingkat kedatangan para wisatawan. Oleh karenanya menurut Kementerian Koordinator Bidang Perekonomian (2011) dalam Masterplan Percepatan dan Perluasan Pembangunan Ekonomi Indonesia (MP3EI) 2011-2025, salah satu cara yang dilakukan pemerintah pusat adalah dengan membangun jalan tol Nusa dua-Ngurah Rai-Tanjung Benoa. Dalam Public Private Partnership Bappenas (2011) disampaikan bahwa dalam perkembangannya wilayah di pulau Bali bagian selatan terutama di daerah Kuta dewasa ini menjadi daerah tujuan utama. Dengan demikian daerah tersebut saat ini menjadi pusat pertumbuhan ekonomi, pendidikan dan tentu saja pariwisata. Namun yang menjadi permasalahan adalah jalan penghubung dari Denpasar menuju Kuta hanya terdapat satu ruas jalan yaitu jalan Ngurah Rai, sehingga pada jam-jam tertentu mengakibatkan kemacetan, karena kapasitas jalan tidak dapat menampung volume kendaraan.

Landasan hukum tentang jalan tol diantaranya mengacu pada UU 38/2004 tentang jalan dan PP 15/2005 tentang jalan tol, dalam Undang-undang dan Peraturan Pemerintah tersebut dijelaskan bahwa jalan tol sebenarnya merupakan jalan alternative dari jalan untuk lalu lintas umum, jalan tol didesain untuk mengurangi kemacetan lalu-lintas di dalam kota maupun di luar kota, jalan tol mempunyai sifat bebas hambatan oleh karenanya pengguna jalan tol diwajibkan untuk membayar tol dan pengguna jalan tol akan mendapatkan fasilitas berupa penghematan biaya operasional, jarak dan waktu tempuh. Jalan tol harus mempunyai spesifikasi dan pelayanan yang lebih tinggi daripada jalan umum yang ada. Begitu pula untuk aspek tingkat pelayanan keamanan dan kenyamanan yang lebih tinggi dari jalan umum yang ada dan dapat melayani arus lalu lintas jarak jauh dengan mobilitas tinggi. Untuk memenuhi hal tersebut maka jalan tol didesain untuk kecepatan tinggi yaitu minimal $60 \mathrm{~km} / \mathrm{jam}$.

Karena tuntutannya yang tinggi, maka penetapan pembangunan suatu jalan tol harus dilakukan pra studi kelayakan dan studi kelayakan terlebih dahulu yang menyatakan bahwa jalan tol tersebut layak untuk dibangun. Namun pada umumnya studi kelayakan lebih menitikberatkan pada resiko finansial, karena hal tersebut menjadi landasan utama para investor. Wibowo, (2006) menyampaikan bahwa investasi infrastruktur (jalan tol) adalah investasi padat modal, berjangka panjang 25 - 30 tahun dan selama horizon investasi investor dihadapkan pada resiko dan ketidakpastian yang tinggi dengan profil senantiasa berubah menurut siklus hidup proyek yang mengakibatkan cashflow proyek sangat sensitive terhadap perubahan.

Resiko financial selama ini menjadi hal yang paling di kaji dalam penyusunan studi kelayakan, padahal Widiantono, dkk (2005) telah menyusun pedoman penilaian resiko 
investasi jalan tol, yang menjadi pedoman teknis Kementerian PU (Pd. T-01-2005-B) yang dapat dijadikan acuan dalam analisa investasi jalan tol. Namun pada umumnya studi kelayakan menggunakan analisa seperti Internal Rate of Return (IRR), Net Presen Value (NPV), Benefit Cost Ratio (BCR), Biaya operasional Kendaraan (BOK), dll. Banyak peneliti yang telah melakukan analisa kelayakan financial pada jalan tol misalnya, Fitriani, dkk (2006), Yana, dkk (2007), Alfian (2011). Kemudian Wibowo, (2012) juga coba melakukan analisa kelayakan investasi jalan tol dilihat dari inflasi keuangan.

Kembali pada Pd. T-01-2005-B, yang disebut analisis resiko adalah proses identifikasi resiko, perkiraan kemungkinan kejadian serta evaluasi dampak potensial yang akan muncul dari suatu rencana kegiatan/proyek secara kualitatif dan kuantitatif. Dalam pedoman tersebut dibahas berbagai macam resiko, salah satunya resiko akibat force majeur yang terdiri dari bencana alam, perubahan kepemimpinan dan kebijakan nasional. Resiko pembangunan suatu proyek tidak selalu masalah financial, terdapat pula resiko-resiko lain yang tidak bisa diprediksi, hal-hal inilah yang yang masuk dalam force majeur. Dalam UU Nomor 18/1999 tentang Jasa Konstruksi menyebutkan bahwa keadaan memaksa/force majeure sebagai suatu kejadian yang timbul di luar kemauan dan kemampuan para pihak yang menimbulkan kerugian bagi salah satu pihak.

Oleh karenanya dalam tulisan ini akan dikaji resiko pembangunan jalan tol Nusa dua-Ngurah Rai-Tanjung Benoa dilihat dari resiko bencana alam, khususnya dilihat dari tingkat kerentanan jalan terhadap bencana Tsunami, hal ini dilakukan dengan 3 cara pengukuran yaitu:

1. Model yang dilakukan oleh Omira et al (2009) yang merupakan pendekatan penelitian tentang assessment kerentanan bangunan di daerah sekitar pantai di Cassablanca - Maroko terhadap Tsunami.

2. Kerentanan terhadap Tsunami dengan Matriks Sengaji dan Nababan (2009). Disampaikan dalam Sengaji dan Nababan (2009) bahwa matrik ini merupakan pengembangan dari kriteriakriteria yang dilakukan oleh Diposaptono dan Budiman (2006) dan Pusat Informasi Riset Bencana Alam (2008), serta penentuan hubungan tingkat kerusakan dengan tinggi (run up) Tsunami menggunakan skala Lida (1963). Pendekatan perhitungan matrik ini dilakukan di Kabupaten Sikka, Nusa Tenggara Timur - Indonesia.

3. Model oleh Kumar et al (2010) tentang perhitungan indek kerentanan daerah pantai atau Coastal Vulnerability Indeks (CVI), model ini merupakan hasil pendekatan penelitian yang dilakukan di Orrisa State Pantai Timur - India. Alasan penggunaan model ini dikarenakan ketinggian kedatangan Tsunami tergantung dari gelombang yang dihasilkan oleh sumber gempa, sehingga letak dan kedalaman terjadinya gempa sangat berpengaruh pada ketinggian Tsunami, tergantung juga terhadap Profil Pantai, Topografi Pantai, dan Struktur Bentuk Pantai. Sehingga untuk lebih memvalidasi tingkat kerentanan jalan tol Nusa Dua - Ngurah Rai - Benoa terhadap Tsunami dilakukan juga perhitungan dengan pendekatan CVI.

Kajian ini dimaksudkan untuk memberikan masukan terhadap instansi terkait sebagai kajian awal untuk penelitian yang lebih komprehensif dan atau sebagai salah satu latar belakang melakukan tindakan-tindakan mitigasi dan adaptasi.

\section{Jalan Tol Nusa Dua - Ngurah Rai - Benoa}

Menurut BPJT (2012), Jalan tol Nusa Dua - Ngurah Rai - Tanjung Benoa dibangun untuk menghubungkan kawasan Bandara Ngurah Rai dengan Kawasan Nusa Dua serta kawasan pelabuhan Benoa (akses Pesanggaran) dengan total panjang 9,702 km. Denah lokasi dapat dilihat pada gambar 1. 


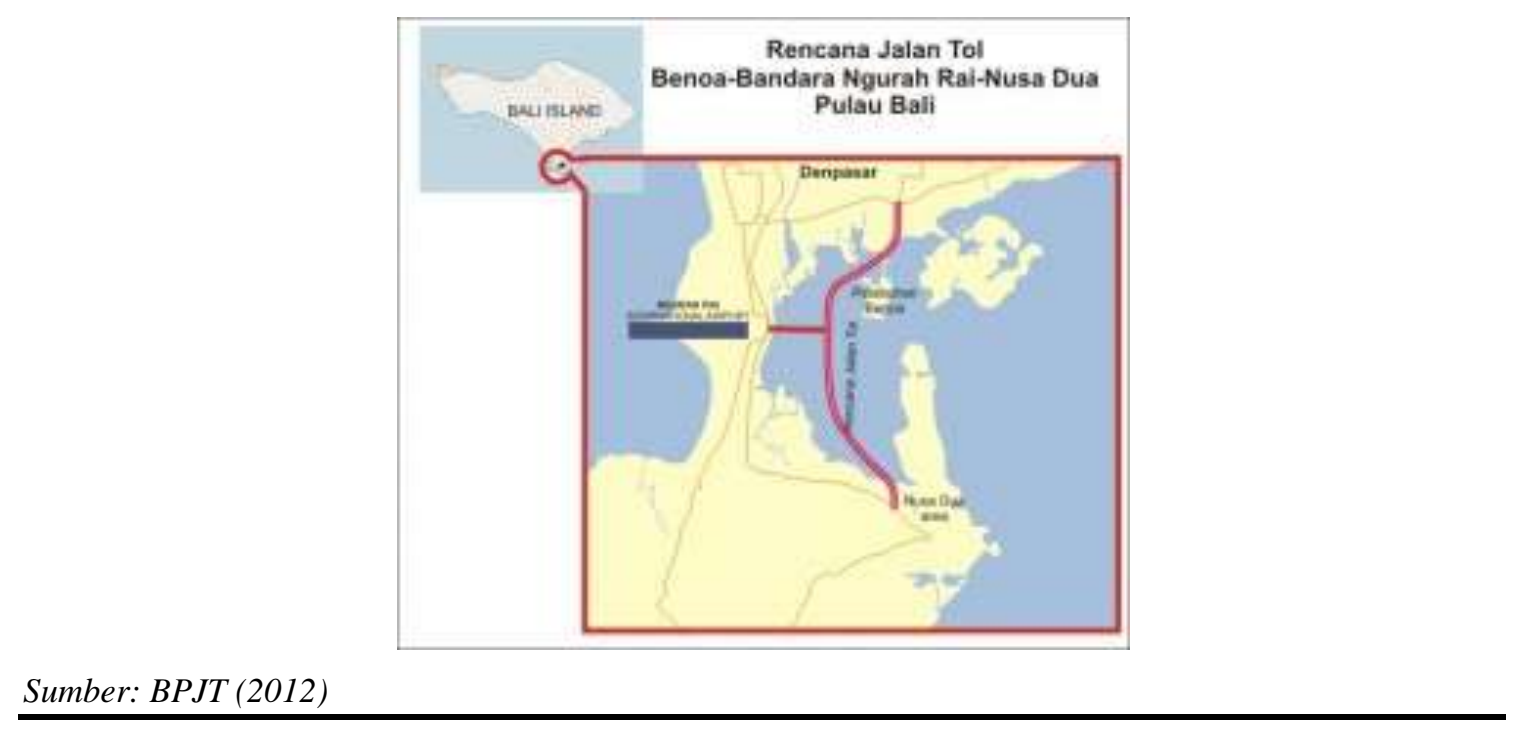

Gambar 1. Denah Lokasi

Sedangkan dalam Public Private Partnership Bappenas (2011) hal-hal teknis terkait dengan jalan tol tersebut adalah:

a. Analisa supply and demand kendaraan bermotor adalah 12.119 kendaraan/hari pada tahun 2011

b. Kecepatan rencana adalah $100 \mathrm{~km} / \mathrm{jam}$

c. Rencana jalan adalah 3 lajur 2 arah

d. Lebar lajur adalah 3,6 meter

e. Lebar bahu jalan luar adalah 3 meter

f. Lebar bahu jalan dalam adalah 1,5 meter

g. Lebar median 5,5 meter

h. Panjang jalan $9.7 \mathrm{~km}$

Kemudian hal yang menarik menurut Suseno, (2012) Jalan tol Nusa dua - Ngurah

Rai - Tanjung Benoa akan dibangun 3 meter diatas permukaan laut. Dengan ketinggiaan muka air laut maksimum yang pernah terjadi adalah 2,4 meter diatas permukaan laut.

\section{Kerentanan Pulau Bali Terhadap Tsunami}

Menurut Rodriguez dan Dorado (2009), Tsunami berasal dari bahasa Jepang yang terdiri dari dua kata yaitu Tsu yang berarti pelabuhan dan Nami yang berarti gelombang.Jika diartikan secara utuh Tsunami adalah rangkaian gelombang yang tercipta ketika sekumpulan air berpindah dengan sangat cepat. Penyebab Tsunami bisa berbagai macam, diantaranya adalah gempa bumi dikedalaman laut, meletusnya gunung berapi di dalam laut atau ledakan didalam laut, tanah longsor atau perpindahan masa di bawah laut, terjadinya tumbukan meteor yang besar, dan sebagai tambahan adalah ledakan dari nuklir yang terjadi di laut. Dalam Rodriguez dan Dorado (2009) dijelaskan proses terjadinya Tsunami dan dapat dilihat pada Gambar 2 sebagai berikut: 


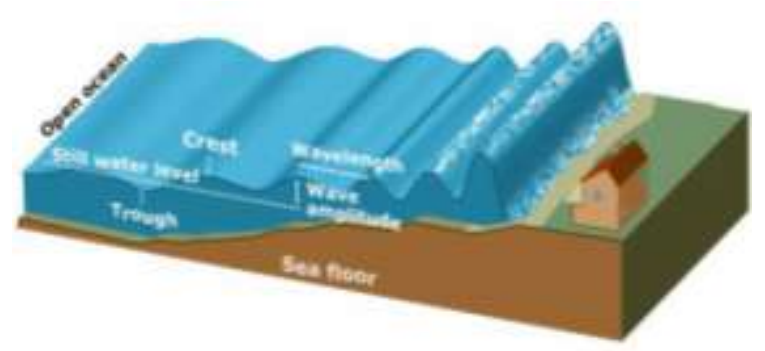

Sumber: Rodriguez dan Dorado (2009)

Gambar 2.Proses Terjadinya Tsunami

Yang menjadi kekhawatiran, berdasarkan laporan GITEWS (German - Indonesian Cooperation for a Tsunami Early Warning System) (2010), Pulau Bali terletak sangat dekat dengan zona tumbukan antara Lempeng Indo-Australia dan Lempeng Erasia. Zona subduksi yang terkait mewakili area sumber utama bagi tsunami yang dapat memengaruhi khususnya bagian selatan pulau ini. Diperkirakan bahwa gelombang tsunami dari area ini hanya memerlukan 30 hingga 60 menit untukmencapai pantai. Catatan riwayat tsunami yang berkaitan dengan zona subduksi ini adalah Tsunami Sumba tahun 1977 dan Tsunami Banyuwangi tahun 1994 yang disebabkan oleh gempa bumi dengan episenter di zona subduksi. Hasil penelitian GITEWS menghasilkan peta kerentanan akibat Tsunami di Pulau Bali yang dapat dilihat pada Gambar 3 sebagai berikut.

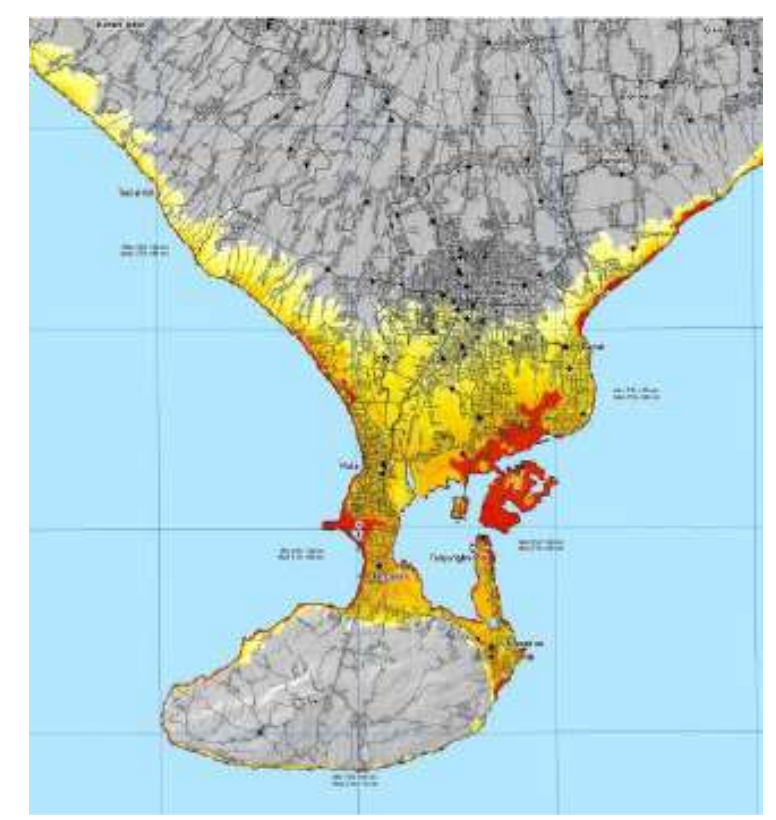

Gambar3.Peta Bahaya Tsunami Skala 1:100.000 
Dari Gambar 3 dapat dilihat bahwa daerah selatan provinsi Bali terutama didaerah tanjung Benoa mempunyai kerentanan yang tinggi (berwarna merah) terhadap Tsunami. Selanjutnya untuk memperjelas pada gambar 3 disajikan gambar detail daerah bahaya Tsunami dengan skala 1:250.000 terutama pada daerah Tanjung Benoa.

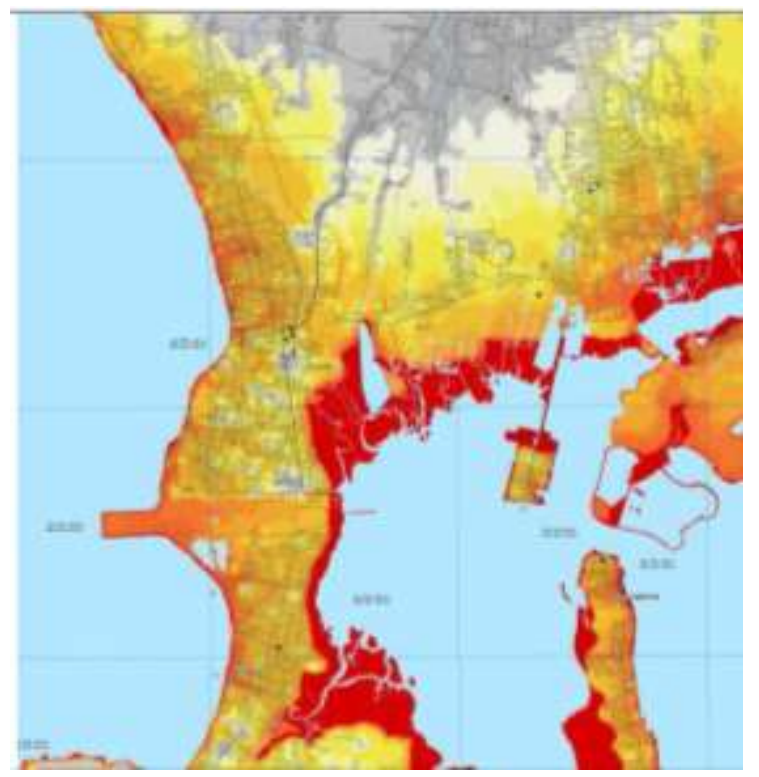

\section{Gambar 4. Peta Bahaya Tsunami Skala 1:250.000}

Dari Gambar 1, Gambar 3 dan Gambar 4 dapat kita ketahui bahwa rencana jalan tol Nusa Dua- Ngurah Rai- Benoa berada pada lokasi yang rawan terhadap bahaya Tsunami. Hal ini sangat masuk akal karena wilayah Indonesia memiliki sabuk vulkanik sepanjang $7.000 \mathrm{~km}$ yang terbentang dari Pulau Sumatra, Jawa, Bali, NTB, serta NTT. Hal ini diperkuat dengan hasil Indek Rawan Bencana Indonesia yang dikeluarkan oleh BNPB (2011) yang menyatakan bahwa pulau Bali mempunyai resiko tinggi terhadap bencana, dengan parameter yang terdiri dari Banjir, Gempa bumi, Tsunami, Kebakaran, Kecelakaan, dll.

\section{Pendekatan Omira et al (2009)}

Persamaan yang digunakan adalah persentase dari Building Tsunami Vulnerability (BTV) dengan persamaan sebagai berikut:

$$
B T V \%=\frac{(3 \times \mathrm{Fcb})+(2 \times \mathrm{Fci})+(1 \times \mathrm{Fcs})}{\sum_{k=1}^{3}(\mathrm{Fcmax} \times \mathrm{Fw}) \mathrm{k}} \times 100(1)
$$

Keterangan:

$\mathrm{Fcb}=$ faktor klasifikasi jenis material bangunan, $\mathrm{Fci}=$ factor zona lokasi bangunan, $\mathrm{Fcs}=$ factor perlindungan bangunan terhadap air laut, $\mathrm{F}_{\mathrm{cmax}}=$ Nilai maksimal dari klasifikasi $\mathrm{k}$, sedangkan $\mathrm{k}=$ jumlah criteria.

Untuk membantu penilaian menggunakan persamaan (1) maka pembagian klasifikasi Fcb, Fci dan Fcs dapat dilihat pada Tabel 1, Tabel 2, dan Tabel 3 sebagai berikut: 
Tabel 1. Faktor Klasifikasi Jenis Material Bangunan

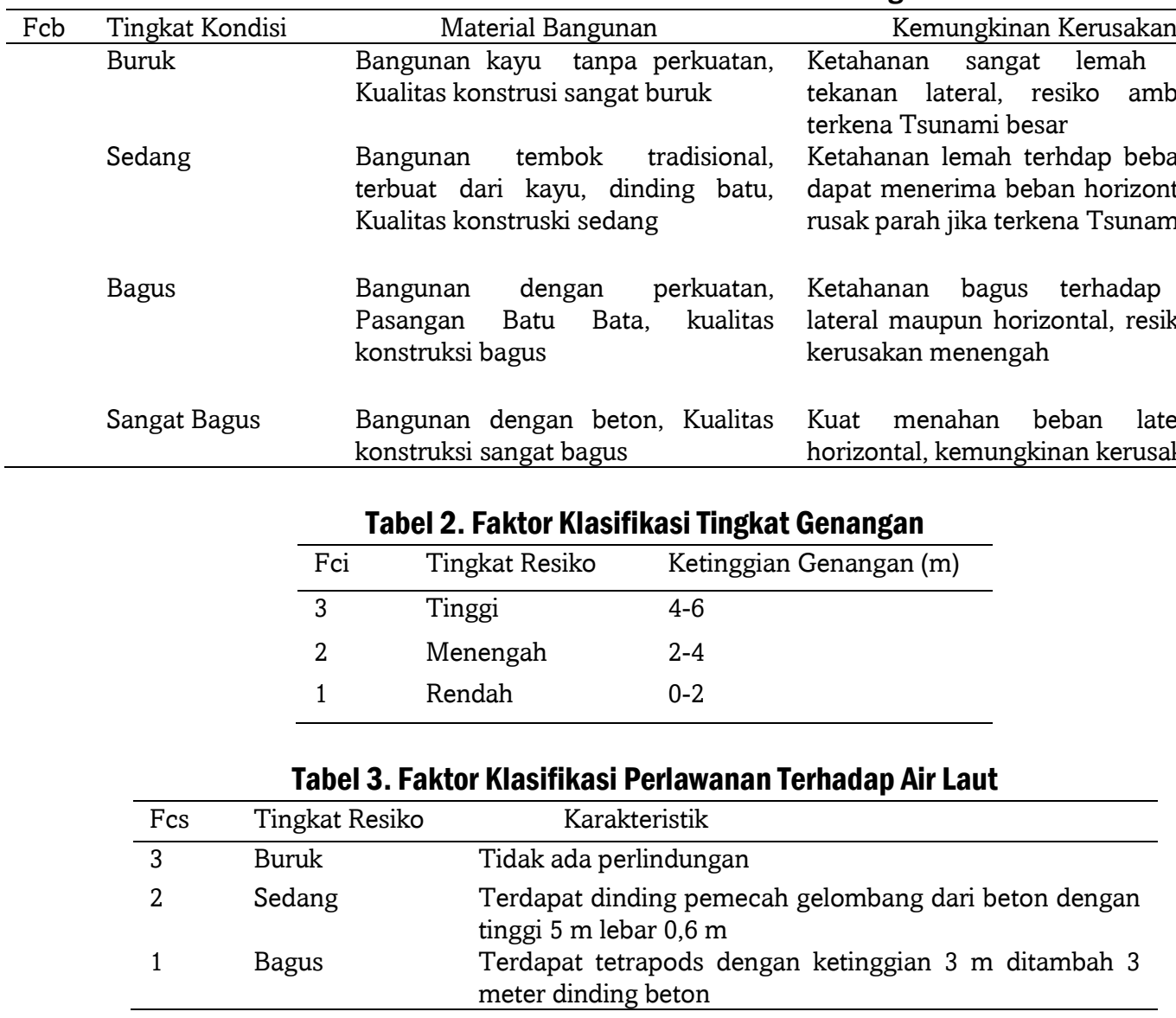

Sedangkan pembagian nilai tingkat kerentanan BTV dibagi menjadi 5, resiko D0 yaitu tanpa kerusakan dengan nilai $0-20 \%$, D1 yaitu kerusakan sedikit tapi tidak ada kerusakan struktur $21-40 \%$, D2 yaitu kerusakan sedang struktur rusak sedikit 41-60\%, D3 yaitu kerusakan parah termasuk struktur $61-80 \%$, D4 yaitu bangunan rubuh semuanya $81-$ $100 \%$

\section{Pendekatan Matriks Sengaji dan Nababan (2009)}

Penentuan tingkat resiko Tsunami dengan pendekatan ini sebenarnya merupakan teknik dengan melakukan overlay data kerawanan per parameter dengan menggunakan metode CBM (Cell Based Modelling) sehingga akan berformat raster dengan ukuran piksel 30 x 30 meter. Namun analisa yang digunakan pada jalan tol ini, dilakukan dengan asumsi bangunan Jalan tol dianggap satu kesatuan secara menyeluruh tidak dibagi per ukuran piksel karena analisa hanya menggunakan parameter-parameter yang ada di Matriks bukan dengan software pemetaan. Pada tabel 4 disajikan Matriks resiko tsunami.

Dari tabel 4 Matrik resiko Tsunami dapat kita ketahui bahwa terdapat 7 parameter untuk menghitung tingkat kerentanan. Nilai dari masing-masing parameter yaitu bobot dikali dengan skor. Persamaan untuk perhitungan ini menurut Pasek (2007) dalam Sengaji dan Nababan (2009) adalah:

$\mathrm{N}=\sum B i x S i$

Keterangan :

$\mathrm{N}=$ Total bobot nilai, $\mathrm{Bi}=$ Bobot pada tiap criteria,

$\mathrm{Si}=$ Skor pada tiap criteria, $\mathrm{i}=$ Parameter 
Tabel 4. Matrik Resiko Tsunami

\begin{tabular}{|c|c|c|c|c|c|c|c|c|c|c|c|c|}
\hline No & Parameter & $\begin{array}{l}\text { Bo } \\
\text { bot } \\
\%\end{array}$ & $\begin{array}{l}\text { Resiko } \\
\text { Sangat } \\
\text { Tinggi }\end{array}$ & $\begin{array}{l}\mathrm{S} \\
\mathrm{k} \\
\mathrm{O} \\
\mathrm{r}\end{array}$ & $\begin{array}{l}\text { Resiko } \\
\text { Tinggi }\end{array}$ & $\begin{array}{l}\mathrm{S} \\
\mathrm{k} \\
\mathrm{O} \\
\mathrm{r}\end{array}$ & $\begin{array}{l}\text { Resiko } \\
\text { Sedang }\end{array}$ & $\begin{array}{l}\mathrm{S} \\
\mathrm{k} \\
\mathrm{O} \\
\mathrm{r}\end{array}$ & $\begin{array}{l}\text { Resiko } \\
\text { Rendah }\end{array}$ & $\begin{array}{l}\text { Sk } \\
\text { or }\end{array}$ & $\begin{array}{l}\text { Resiko } \\
\text { Sangat } \\
\text { Rendah }\end{array}$ & $\begin{array}{l}\mathrm{S} \\
\mathrm{k} \\
\mathrm{O} \\
\mathrm{r}\end{array}$ \\
\hline 1 & $\begin{array}{l}\text { Kerawanan } \\
\text { Tinggi } \\
\text { Tsunami (m) } \\
\text { Kerentanan }\end{array}$ & 20 & $>16$ & 5 & $>6-16$ & 4 & $>2-6$ & 3 & $>0,75-2$ & 2 & $<0,75$ & 1 \\
\hline 2 & Elevasi (m) & 15 & $<10$ & 5 & $>10-25$ & 4 & $>25-50$ & 3 & $>50-100$ & 2 & $>100$ & 1 \\
\hline 3 & Slope (\%) & 15 & $<10$ & 5 & $10-20$ & 4 & $>20-30$ & 3 & $>30-40$ & 2 & $>40$ & 1 \\
\hline 4 & $\begin{array}{l}\text { Morfometri } \\
\text { Pantai }\end{array}$ & 15 & Teluk V & 5 & Teluk U & 4 & $\begin{array}{l}\text { Tanjun } \\
\mathrm{g}\end{array}$ & 3 & Lurus & 2 & $\begin{array}{l}\text { Non } \\
\text { Teluk / } \\
\text { Tanjung }\end{array}$ & 1 \\
\hline 5 & Landuse & 10 & $\begin{array}{l}\text { Rumah, } \\
\text { Sawah, } \\
\text { Bakau, } \\
\text { Hutan, } \\
\text { Rawa }\end{array}$ & 5 & Kebun & 4 & $\begin{array}{l}\text { Ladang } \\
\text { / } \\
\text { Kebon }\end{array}$ & 3 & $\begin{array}{l}\text { Semak } \\
\text { belukar, } \\
\text { tanah } \\
\text { kosong }\end{array}$ & 2 & $\begin{array}{l}\text { Hutan, } \\
\text { batuan } \\
\text { cadas, } \\
\text { Gamping }\end{array}$ & 1 \\
\hline 6 & $\begin{array}{lr}\text { Jarak } & \text { dari } \\
\text { Garis } & \text { Pantai } \\
(\mathrm{m}) & \end{array}$ & 15 & $0-200$ & 5 & $\begin{array}{l}>200- \\
500\end{array}$ & 4 & $\begin{array}{l}>500- \\
1000\end{array}$ & 3 & $\begin{array}{l}>1000- \\
1500\end{array}$ & 2 & $>1500$ & 1 \\
\hline 7 & $\begin{array}{l}\text { Jarak dari } \\
\text { Sungai }(m)\end{array}$ & 10 & $0-100$ & 5 & $\begin{array}{l}>100- \\
200\end{array}$ & 4 & $\begin{array}{l}>200- \\
300\end{array}$ & 3 & $>300-500$ & 2 & $>500$ & 1 \\
\hline Jum & ah bobot x Skor & $\begin{array}{l}10 \\
0\end{array}$ & & 5 & & 4 & & 3 & & 2 & & 1 \\
\hline
\end{tabular}

Selanjutnya untuk menentukan tingkat kerentanan terhadap Tsunami adalah dengan melakukan jumlah perkalian nilai maksimum dari tiap bobot dan skor dikurangi jumlah perkalian nilai minimumnya yang kemudian dibagi dengan jumlah pengklasifikasian tingkat kelas. Persamaan Kelas Resiko (KR) dapat dilihat sebagai berikut:

$$
K R=\frac{\left(\sum(B i x S i) \max -\sum(B i x S i) \min \right)}{n}
$$

Keterangan:

$\mathrm{KR}=$ tingkat resiko, $\mathrm{n}=$ jumlah kelas

Pengklasifikasian tingkat kelas resiko Tsunami ditetapkan dibagi menjadi lima, hal tersebut dapat dilihat pada tabel 5 sebagai berikut :

Tabel 5. Tingkat Kelas Resiko Tsunami

\begin{tabular}{rll}
\hline \multicolumn{1}{c}{ KR } & \multicolumn{1}{c}{ Nilai KR } & \multicolumn{1}{c}{ Resiko } \\
\hline Kelas R1 & $1 \leq \mathrm{N} \leq 1.8$ & Sangat Rendah \\
Kelas R2 & $1,81 \leq \mathrm{N} \leq 2,6$ & Rendah \\
Kelas R3 & $2,61 \leq \mathrm{N} \leq 3,4$ & Sedang \\
Kelas R4 & $3,41<\mathrm{N}<4,2$ & Tinggi \\
Kelas R5 & $4,21<\mathrm{N}<5$ & Sangat Tinggi \\
\hline
\end{tabular}

\section{Pendekatan Model Kumar et al (2010)}

Aplikasi perhitungan dengan model ini sebenarnya menggunakan cara membagi daerah yang diteliti menjadi persegmen dengan ukuran $1 \mathrm{~km}$ persegi, namun analisa yang digunakan pada jalan tol ini tidak dilakukan demikian, hal ini disebabkan parameterparameter yang digunakan sepanjang jalan tol sebagian besar sama, hanya parameter geomorfologi pantai yang berbeda, sehingga perhitungan yang kerentanan jalan tol diasumsikan sebagai satu kesatuan secara menyeluruh. Alasan lain penggunaan model ini untuk analisa kerentanan jalan tol Nusa Dua - Ngurah Rai - Benoa dikarenakan didalam 
model tersebut terdapat parameter run up Tsunami, serta lokasi jalan tol tersebut memang berada didaerah sekitar pantai, sehingga penggunaan model ini dianggap relevan. Persamaan Coastal Vulnerability Indeks (CVI) adalah sebagai berikut:

$$
C V I=\sqrt{(A x B x D x E x F x G x H) / 8}
$$

Keterangan:

$\mathrm{A}=$ resiko akibat perubahan garis pantai, $\mathrm{B}=$ resiko akibat perubahan muka air laut, $\mathrm{C}=$ resiko akibat kemiringan lereng pantai, $\mathrm{D}=$ resiko akibat ketinggian ombak maksimal, $\mathrm{E}=$ resiko akibat pasang surut air laut, $\mathrm{F}=$ resiko akibat ketinggian daerah pantai, $\mathrm{G}=$ resiko akibat geomorfologi pantai, $\mathrm{H}=$ resiko akibat ketinggian Tsunami yang pernah terjadi.

Untuk mempermudah perhitungan menggunakan persamaan CVI, maka perlu dilakukan klasifikasi parameter yang dapat dilihat pada tabel 6 Klasifikasi rating resiko sebagai berikut:

Tabel 6. Klasifikasi Rating Resiko

\begin{tabular}{|c|c|c|c|}
\hline \multirow[t]{2}{*}{ Variabel } & \multicolumn{3}{|c|}{ Rating Resiko } \\
\hline & Rendah (1) & Sedang (2) & High (3) \\
\hline Perubahan garis pantai (m/th) & $>0$ & $(-10)-0$ & $<(-10)$ \\
\hline Perubahan muka air laut (mm/th) & 0 & $0-1$ & $1-<2$ \\
\hline Kemiringan lereng pantai (derajat) & $>1$ & $0.2-1$ & $0-0.2$ \\
\hline Ketinggian ombak maksimal (m) & $<1.25$ & $1.25-1.4$ & $>1.4$ \\
\hline Pasang surut air laut (m) & $<2.5$ & $2.5-3.5$ & $>3.5$ \\
\hline Ketinggian daerah pantai (m) & $>6$ & $3-6$ & $0-3$ \\
\hline Geomorfologi pantai & Jurang, tebing & $\begin{array}{l}\text { Muara, } \\
\text { bervegetasi }\end{array}$ & $\begin{array}{l}\text { Pasir pantai, hutan } \\
\text { mangrove }\end{array}$ \\
\hline Ketinggian Tsunami yang terjadi (m) & $0-1$ & $1-2$ & $>2$ \\
\hline
\end{tabular}

Pembagian tingkat kerentanan CVI dalam Kumar et al (2009) sebenarnya dibagi berdasarkan nilai prosentase dari daerah yang diamati menggunakan teknik penghitungan vector menggunakan program ESRI ArcMap Software, namun pada pembagian tingkat kerentanan kali ini menggunakan cara nilai CVI maksimal kemudian dibagi menjadi 5 kelas yaitu KR1 nilai< 5,72 yang berarti resiko sangat rendah, KR2 nilai 5,73 - 11,46 yang berarti resiko rendah, KR3 nilai 11,47-17,18 yang berarti resiko sedang, KR4 nilai 17,19-22,91 yang berarti resiko tinggi, dan KR5 dengan nilai >22,91 yang berarti resiko sangat tinggi.

\section{Metodologi}

Metodologi yang digunakan untuk menghitung tingkat kerentaan adalah:

1. Mengumpulkan data-data teknis Jalan Tol Nusa Dua - Ngurah Rai - Benoa yang berupa data sekunder dari instansi terkait seperti BPJT, Jasa marga, Pemprov Bali, BNPB, LAPAN, BMKG, dll.

2. Mengklasifikasi data teknis Jalan Tol Nusa Dua - Ngurah Rai - Benoa sesuai dengan parameter pada persamaan (1) Model Omira et al (2009), kemudian melakukan perhitungan dengan persamaan tersebut.

3. Penggunaan aplikasi penginderaan jauh untuk mengetahui parameter-parameter yang digunakan dalam perhitungan matrik Sengaji dan Nababan (2009) diantaranya klasifikasi Landuse, Morfometri Pantai, Kemiringan Slope, Jarak jalan tol dari pantai dan jarak dari sungai. Sedangkan untuk parameter Run up Tsunami yang pernah terjadi di sekitar daerah penelitian menggunakan data sekunder dari BMKG. Setelah data didapatkan langkah selanjutnya adalah melakukan perhitungan dengan Matrik bahaya Tsunami dan perhitungan menggunakan persamaan (2) serta untuk melihat tingkat kelas resiko menggunakan persamaan (3).

4. Aplikasi penginderaan jauh juga masih digunakan untuk mengukur parameter-kemiringan lereng pantai, ketinggian daerah pantai, dan geomorfologi pantai yang ada pada persamaan (4) 
yaitu model oleh Kumar (2010). Kemudian mencari data perubahan muka air laut, data ketinggian ombak maksimal, data pasang surut air laut, perubahan garis pantai, dan ketinggian Tsunami yang pernah terjadi. Setelah data didapatkan maka dilakukan perhitungan dengan persamaan (4).

5. Interpretasi dari hasil perhitungan persamaan (1), perhitungan Matrik Tabel 4, persamaan (2) dan (3), serta hasil perhitungan persamaan (4).

\section{Hasil Dan Kajian}

Analisa perhitungan dengan menggunakan Model Omira et al (2009) berdasarkan data teknis yang digunakan yaitu klasifikasi jenis material bangunan jalan tol adalah beton bertulang, tingkat genangan air diasumsikan pada resiko rendah karena jalan tol ini berada di atas permukaan laut, dan klasifikasi perlawanan akibat gelombang air laut adalah tidak ada perlindungan, maka dengan persamaan (1) didapatkan hasil perhitungan kerentanan Jalan Tol Nusa Dua - Ngurah Rai - Benoa, nilai BTV adalah 30\%. Nilai ini termasuk dalam D1 yang artinya terdapat sedikit kerusakan namun tidak ada kerusakan pada struktur. Hal ini dikarenakan dalam persamaan (1) bobot nilai untuk jenis material bangunan mempunyai nilai paling tinggi yaitu 3 sehingga bangunan dengan beton mempunyai kekuatan struktur yang mampu menahan Tsunami, walaupun tidak terdapat perlindungan terhadap bangunan namun bobot pada parameter ini hanya l sehingga tidak berpengaruh signifikan.

Selanjutnya perhitungan dengan menggunakan Matrik Sengaji dan Nababan (2009) pada Tabel 4, dengan klasifikasi data kemiringan slope diambil 0 derajat karena Jalan tol berada diatas laut, Morfometri Pantai termasuk jenis teluk V, tata guna lahan dimasukkan dalam kategori mangrove dan hutan rawa. Sedangkan jarak dari pantai dan jarak dari sungai diambil yang paling maksimal karena Jalan Tol berada di atas permukaan laut. Run up Tsunami diambil berdasarkan pada Tsunami Flores tahun 1992 dengan ketinggian gelombang 10 meter, dengan rencana pembangunan jalan tol berada pada ketinggian 3 meter diatas permukaan laut. Sehingga tingkat kerentanan Jalan tol Nusa Dua - Ngurah Rai - Benoa berdasarakan matrik bahaya tsunami, persamaan (2) dan persamaan (3) maka didapatkan nilai 4 yang berarti masuk pada Kelas Resiko (KR) 4 yang artinya mempunyai resiko tinggi, hal ini terjadi karena hampir semua parameter dalam matrik nilai skornya adalah 5 sehingga selisih $\mathrm{N}_{\text {Maks }}-\mathrm{N}_{\text {Minsangat kecil. }}$

Terakhir, dengan pendekatan dari model Kumar et al (2009) berdasarkan data yang didapatkan kemiringan lereng pantai, ketinggian daerah pantai, dan geomorfologi pantai. Kemudian data perubahan muka air laut diatas $2 \mathrm{~mm} /$ tahun, kemudian berdasarkan data Pantai Candikusuma, Cupel, dan Perancak di Kabupaten Jembrana, perubahan garis pantai 20 meter per tahun, ketinggian ombak maksimal dan pasang surut air laut adalah 2-3 meter dan 0.9 meter, ketinggian Tsunami yang pernah terjadi didasarkan pada Tsunami Flores tahun 1992 yaitu 10 meter. Dengan menggunakan persamaan (4) maka didapatkan hasil 16,53 yang artinya mempunyai resiko sedang. Parameter yang berpengaruh pada hasil tersebut adalah parameter pasang surut yang bernilai rendah, data diambil dari data kelautan LAPAN di stasiun Bali - Pengambengan.

Dari ketiga pendekatan yang dilakukan diatas diketahui bahwa terdapat perbedaan dari masing-masing pendekatan, hal ini disebabkan tiap pendekatan mempunyai parameter yang berbeda sehingga tidak bisa dibandingkan secara langsung satu dengan yang lain, namun yang perlu di perhatikan adalah bahwa jalan tol tersebut mempunyai kerentanan terhadap Tsunami. Seperti telah disampaikan pada bagian pendahuluan bahwa investasi pembangunan Jalan tol membutuhkan modal yang sangat besar dan merupakan investasi jangka panjang, sehingga perlu dilakukan kajian yang komprehensif terhadap kemungkinan-kemungkinan yang dapat membahayakan jalan tol di masa yang akan datang untuk menghindari hal-hal yang merugikan. 


\section{Kesimpulan Dan Saran}

\section{Kesimpulan}

Dari uraian yang telah dilakukan, dapat diambil kesimpulan:

1. Kerentanan Tsunami dengan pendekatan BTV masuk pada kategori D1 yang artinya terdapat sedikit kerusakan namun tidak ada kerusakan pada struktur.

2. Kerentanan Tsunami dengan pendekatan Matriks masuk pada kategori resiko tinggi.

3. Kerentanan Tsunami dengan pendekatan CVI masuk pada kategori resiko sedang.

\section{Saran}

1. Perlu dilakukan validasi untuk mendapatkan hasil yang lebih komprehensif, dengan menggunakan data yang paling terkini.

2. Perlu dilakukan perhitungan dengan menggunakan metode atau pemodelan yang lain sehingga dapat dihasilkan nilai kerentanan yang lebih variatif dan dapat dijadikan pembanding.

3. Perlu dilakukan analisa kerentanan dengan metode simulasi kenaikan muka air laut dan ketinggian ombak, atau ketinggian gelombang Tsunami sehingga dapat diketahui perkiraan Jalan tol tersebut paling rentan (resiko sangat tinggi) jika mendapatkan perlakukan tertentu pada kadar tertentu dan waktu tertentu.

\section{Daftar Pustaka}

Alfian, 2011.Pendekatan Stokastik dalam Kajian Kelayakan Pembangunan Jalan Tol Studi Kasus Rencana Ruas Tol Kandis - Dumai, Jurnal Teknobiologi, II(1) 2011: 41 - 48, Riau

BNPB, 2011.Indeks Rawan Bencana Indonesia, Badan Nasional Penanggulangan Bencana, Jakarta

Bappenas, 2011.Public Private Partnership Infrastructure Project Plan in Indonesia,Jakarta

BPJT, 2012),Jalan Tol Nusa Dua - Ngurah Rai - Benoa(Online). Available at http://www.bpjt.net/main.php?stateid=berita_detail\&pageid=295\&cat=26\&strlang=id

Diakses pada tanggal 15 september 2012

BPS, 2012.Perkembangan Jumlah Kendaraan Bermotor Menurut Jenis tahun 1987-2010(Online). Available at http://www.bps.go.id/tab sub/view.php?kat=2\&tabel=1\&daftar=1\&id subyek=17\&notab=12 Diakses pada tanggal 15 September 2012 di

Fitriani, Heni dkk.2006,Kajian Penerapan Model NPV-at-Risk Sebagai Alat Untuk Melakukan Evaluasi Investasi Pada Proyek Infrastruktur Jalan Tol, Jurnal Infrastruktur dan Lingkungan Binaan Volume II no. 1 Juni 2006, Hal 1-12, Bandung

GITEWS, 2010.Dokumen Teknis Peta Bahaya Tsunami Bali, DLR / GTZ, Bali

Kumar et al, 2010. Coastal Vulnerability Assessment for Orissa State,East Coast of India, Journal of Coastal Research vol 26 no.3 May 2010, Hal 523-534, Florida.

Omira et al, 2009. Tsunami vulnerability Assessment of Casablanca-Morocco using numerical modelling and GIS tools, Springer Science Business Media B.V. 2009

Pemda Provinsi Bali, 2009.Peraturan Daerah Provinsi Bali Nomor 6 Tahun 2009 tentang Rencana Pembangunan Jangka Panjang Daerah (RPJPD) Provinsi Bali Tahun 2005 - 2025, Bali

Pemerintah Republik Indonesia, 1999.Undang-undang Nomor 18 Tahun 1999 tentang Jasa Konstruksi, Jakarta

Pemerintah Republik Indonesia, 2004.Undang-undang Nomor 38 Tahun 2004 Tentang Jalan, Jakarta

Pemerintah Republik Indonesia, 2005.Peraturan Pemerintah Republik Indonesia No 15 Tahun 2005 Tentang Jalan Tol, Jakarta

Rodriguez dan Dorado, 2009.Assessing Tsunami Vulnerability Using MCE in Phang Nga Thailand, Master Thesis Royal Institute of Technology (KTH), Sweden

Sengaji dan Nababan, 2009.Pemetaan Tingkat Resiko Tsunami di Kabupaten Sikka Nusa Tenggara Timur, Jurnal Ilmu dan Teknologi Kelautan Tropis Vol 1, no.1 Juni 2009, Hal 48-61, Bogor 
Suseno, Drajad, 2012.Dibangun 3 Meter di Atas Laut, Tol Nusa Dua-Benoa Dijamin Aman (Online). available at http://finance.detik.com/read/2012/07/29/171730/1977711/4/dibangun-3-meter-di-atas-laut-tolnusa-dua-benoa-dijamin-aman?f9911033 Diakses pada tanggal 15 September 2012

Kementerian Koordinator Bidang Perekonomian, 2011. Masterplan Percepatan dan Perluasan Pembangunan Ekonomi Indonesia (MP3EI) 2011-2025, Jakarta

Wibowo, Andreas, 2006. Regulasi Tarif Sistem Hibrid Alternatif Untuk Proyek Privatisasi Infrastruktur Beresiko Tinggi, Jurnal Teknik Sipil Volume 13 No. 2 April 2006, Hal 67-77, Bandung

Wibowo, Andreas, 2012.Inflasi dalam Analisis Finansial Investasi Jalan Tol:Perlakuan dan Pengaruhnya bagi Badan Usaha dan Pemerintah, Jurnal Teknik Sipil Vol. 19 No. 1 April 2012, hal 15-24, Bandung

Widiantono, Doni dkk, 2005.Pedoman penilaian resiko investasi jalan tol (Pd T01-2005-B), Kementerian Pekerjaan Umum, Jakarta

Yana, Agung dkk, 2007.Studi Kelayakan Jalan Tol Pengambengan - Pengragoan, Jurnal Ilmiah Teknik Sipil Volume 11 no.1 Januari 2007, Hal 39-44, Bali 